\begin{tabular}{c} 
Brazilian Journal \\
of Chemical \\
Engineering \\
\hline
\end{tabular}

ISSN 0104-6632

Printed in Brazil

www.abeq.org.br/bjche

Vol. 31, No. 01, pp. 27 - 33, January - March, 2014

\title{
SEQUENCING BATCH REACTOR OPERATION FOR TREATING WASTEWATER WITH AEROBIC GRANULAR SLUDGE
}

\author{
M. K. Jungles ${ }^{*}$, J. L. Campos ${ }^{2}$ and R. H. R. $\operatorname{Costa}^{1}$ \\ ${ }^{1}$ Department of Sanitary and Environmental Engineering, Federal University of Santa Catarina - \\ UFSC/CTC/ENS, + (55) (48) 3721 7743, CEP: 88010 970, Florianópolis - SC, Brazil. \\ E-mail: marielejungles@ens.ufsc.br \\ ${ }^{2}$ Department of Chemical Engineering, School of Engineering, University of Santiago de Compostela, \\ Lope Gómez de Marzoa s/n, E-15782, Santiago de Compostela, Spain. \\ (Submitted: December 19, 2012 ; Revised: April 23, 2013 ; Accepted: April 23, 2013)
}

\begin{abstract}
In this work, the performance of a sequencing batch reactor (SBR) on aerobic granular sludge was studied for urban wastewater treatment. The system was inoculated with aerobic activated sludge collected from a wastewater treatment plant and, after 30 days of operation, the first granules observed had an average diameter of $0.1 \mathrm{~mm}$. The biomass concentration reached a maximum value around $4 \mathrm{~g} \mathrm{VSS} \mathrm{L}^{-1}$, and COD removal and nitrification efficiency achieved stable values of $90 \%$. The predominant oxidizing ammonium bacteria in the granules were identified as Nitrosomonas spp.

Keywords: Aerobic granulation; Nitrification; Wastewater; SBR.
\end{abstract}

\section{INTRODUCTION}

The development of aerobic granules has recently been studied as a method of improving conventional activated sludge processes due to its applications in removing organic matter, nitrogen, and phosphorus compounds from wastewater (de Kreuk et al., 2005a). Aerobic granular technology presents several advantages compared to activated sludge processes. These include good biomass retention, the ability to withstand shock and toxic loadings, and the presence of both aerobic and anoxic zones inside the granules which can simultaneously permit different biological processes (Beun et al., 1999). In such systems, the biomass grows as compact and dense microbial granules, which allows better biomass retention in the reactor, and, consequently, high biomass concentrations. Therefore, these systems have lower space requirements than systems relying on activated sludge.

The key operational factors that promote the granulation have already been established, and granular sludge from different kinds of industrial wastewater can be grown in sequencing batch reactors (SBRs) (de Kreuk and van Loosdrecht, 2006; Arrojo et al., 2004; Inizan et al., 2005; Schwarzenbeck et al., 2005; Wang et al., 2007) under different operational conditions such as oxygen limitation or low temperature (de Kreuket al., 2005b). However, only a few works apply this technology to sewage (Jungles et al., 2011). Additionally, most of these works were conducted on laboratory scales with only a few conducted on pilot scales (de Kreuket al., 2005a; de Bruin et al., 2005; Tayet al., 2005). Scaleup of granular systems modifies hydrodynamic conditions, which have large effects on both the formation and stability of aerobic granules.

In Brazil, many small communities lack wastewater treatment facilities. The low space requirement, simplicity and operational flexibility of aerobic granular systems make it possible to apply this technology for sewage treatment in such communities. Therefore, the objective of this work is to evaluate

*To whom correspondence should be addressed 
the performance of a pilot granular aerobic SBR in treating sewage by measuring carbon, nitrogen, and phosphorous removal efficiencies under fluctuating loading rates and relatively high temperatures. Additionally, special attention was paid to the morphological properties and evolution of the granular biomass.

\section{MATERIAL AND METHODS}

\section{Experimental Set-Up}

A reactor with a total volume of $11 \mathrm{~L}$ and a working volume of $9 \mathrm{~L}$ was used. It consisted of a closed cylindrical poly(methyl methacrylate) vessel with a height of $1.90 \mathrm{~m}$, a diameter of $0.09 \mathrm{~m}$, and a minimum level after effluent withdrawal of $0.88 \mathrm{~m}$. The effective height to diameter ratio (H/D) was 19.5 (Figueroa et al., 2009) (Figure 1).

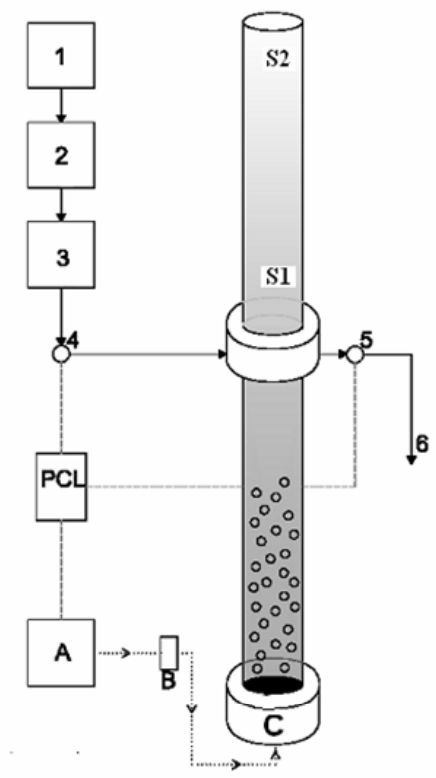

Figure 1: Experimental lab-scale reactor. (1) Influent pump. (2) Storage tank. (3) Mixing tank. (PLC) Programmable logic controller. (4) Feeding pump. (5) Effluent pump (6) Effluent. (A) Air compressor. (B) Air valve. (C) Fine bubble diffuser. (S1) Minimum level sensor. (S2) Maximum level sensor.

Air was supplied at a flow rate of $240 \mathrm{~L} \mathrm{~h}^{-1}$ through a fine bubble dome diffuser placed at the bottom of the reactor, which allowed the formation of small bubbles. This provided the tank with oxygenation and guaranteed complete mixing.

Influent was introduced in the system through an opening located at the middle of the reactor by means of a centrifugal pump. Another pump was utilized to discharge the effluent through a different opening located halfway up the reactor. The whole system was controlled by a programmable logic controller (PLC; Siemens model: AG-A5E0038083902).

\section{Operational Conditions}

The system was operated at 3 hour cycles according to Table 1 . The exchange volume ratio was $50 \%$, and the hydraulic retention time (HRT) was maintained at 0.25 days. The reactor operated at room temperature $\left(16-27{ }^{\circ} \mathrm{C}\right)$ without $\mathrm{pH}$ control, and dissolved oxygen (DO) concentrations during operational cycles remained higher than $4 \mathrm{mg} \mathrm{O}_{2} \mathrm{~L}^{-1}$ during the feast period.

Table 1: Operational cycle distribution.

\begin{tabular}{|l|r|}
\hline Feeding (min) & 1 \\
Aerobic reaction (min) & 168 \\
Settling (min) & 10 \\
Effluent withdrawal (min) & 1 \\
\hline
\end{tabular}

The system was inoculated with $3.5 \mathrm{~L}$ of activated sludge (23 g Total Suspended Solids TSS $\mathrm{L}^{-1}$ ) collected from a municipal wastewater treatment plant (WWTP).

\section{Feeding Media}

Urban wastewater was used as a substrate for microorganisms. COD concentrations were around 160 to $200 \mathrm{mg} \mathrm{COD} \mathrm{L}^{-1}$. Since these values were lower than that recommended for guaranteed granule formation (Beun et al. 2002), a synthetic medium was added to maintain inlet COD concentrations of around $600 \mathrm{mg} \mathrm{COD} \mathrm{L}^{-1}$ (Table 2). The synthetic medium was added because the effluent suffered many variations due to the occurrence of rain, thus sharply lowering the concentrations of COD affecting the grain (less than $100 \mathrm{mg} \mathrm{L}^{-1}$ ), causing the biomass forming the granules to be washed out of the reactor and the system affected by little food.

\section{Table 2: Feeding media used in this study.}

\begin{tabular}{|l|c|}
\hline Compounds & Concentration $\mathbf{g L}^{-\mathbf{1}}$ \\
\hline $\mathrm{CH}_{3} \mathrm{COONa} \cdot 3 \mathrm{H}_{2} \mathrm{O}$ & 2.0 \\
$\mathrm{NH}_{4}{ }^{+}$ & 0.040 \\
$\mathrm{PO}_{4}{ }^{3-}$ & 0.014 \\
$\mathrm{NaCl}^{2-}$ & 0.080 \\
$\mathrm{SO}_{4}{ }^{2-}$ & 0.012 \\
\hline
\end{tabular}




\section{Analytical Methods}

The samples were filtered with a membrane of pore size $45 \mu \mathrm{m}$ (MF Millipore ${ }^{\circledR}$ Membrane, MCE, $0.45 \mu \mathrm{m}, 47 \mathrm{~mm}$ ). The $\mathrm{pH}$ values and $\mathrm{DO}$, nitrate, nitrite, ammonia, phosphate, and volatile suspended solids (VSS) concentrations were determined according to Standard Methods (APHA-AWWA-WPCF 1998). Sludge volumetric index (SVI) values were measured according to Ramalho (1991). Chemical Oxygen Demand (COD) concentrations were determined according to Soto et al. (1989), and granule morphology and size distribution were regularly measured according to Tijhuis et al. (1994). Scanning electron microscopy (SEM) and fluorescence in situ hybridization (FISH) were used to track the evolution of microbial populations.

Biomass samples from the reactor were collected, disrupted, and fixed with 4\% paraformaldehyde solution, as described by Amann et al. (1995). Hybridization was performed at $46^{\circ} \mathrm{C}$ for 90 minutes, and bacterial cells were hybridized and detected with the following FISH probes: the EUB338 mix for members of the domain Bacteria; Nso 190 for the majority of ammonium oxidizing bacteria (AOBs) of the $\beta$-Proteobacteria; NIT3 for nitrite oxidizing bacteria (NOBs); and NEU653 for halophilic and halotolerant Nitrosomonas spp. Details on these oligonucleotide probes are available at probeBase (Loy et al., 2007). The 5' ends of the probes were labeled with FITC fluorochromes. Fluorescence signals were recorded using an acquisition system coupled to an epifluorescence microscope.

\section{RESULTS AND DISCUSSION}

\section{Granule Formation and Properties}

Most of the initial biomass washed out during the first days of operation because the biomass settling velocity was lower than $5.3 \mathrm{~m} \mathrm{~h}^{-1}$. This is the biomass settling velocity required for biomass retention by the system. After 30 days of operation, small granules with an average diameter of $1 \mathrm{~mm}$ were observed (Figure 2(a)). The average diameter of granules increased over the course of the operational period, and the average diameter was $4 \mathrm{~mm}$ at the end of the experiment (Figure 2(b)).

The diameters of granules found in urban sewage are smaller than those found in other types of effluents (Zhang et al., 2005). Small granules formed at the beginning of the operation in this study and their diameters gradually increased over the entire operating period. These granules were larger in diameter than those seen in other wastewater studies (Tayet al., 2003; Weber et al., 2007).

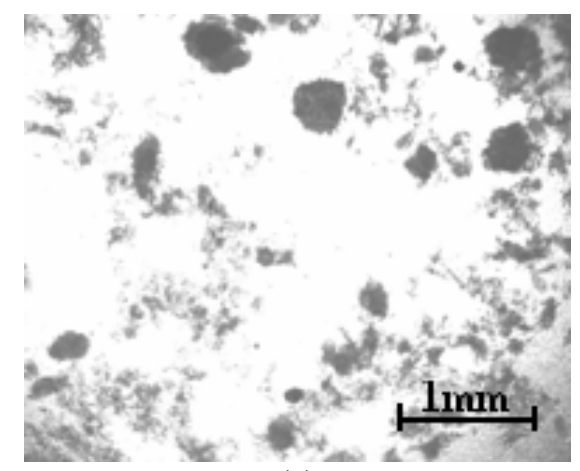

(a)

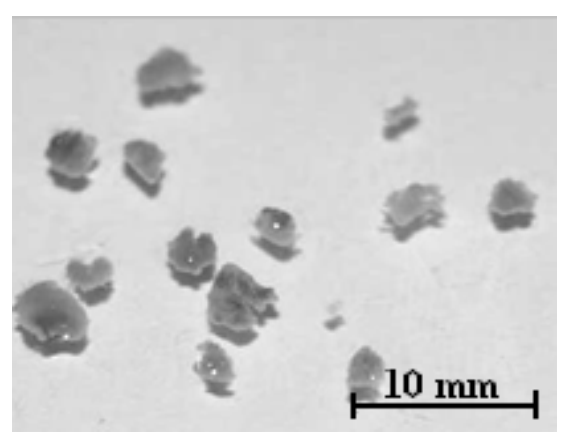

(b)

Figure 2: The evolution of biomass in the granular reactor throughout the operational period at (a) day 30 and (b) day 200.

Ni et al. (2009) succeeded in forming aerobic granules by using a SBR that treated urban wastewater with a COD concentration around $200 \mathrm{mg} \mathrm{L}^{-1}$. After 300 days of operation, a biomass concentration of $9.5 \mathrm{~g} \mathrm{VSS} \mathrm{L}^{-1}$ was achieved, and the diameter of the formed granules was between 0.2 and $0.8 \mathrm{~mm}$.

The solids concentration in the reactor increased from $0.94 \mathrm{~g} \mathrm{VSS} \mathrm{L}^{-1}$ on day 8 to $3.92 \mathrm{~g} \mathrm{VSS} \mathrm{L}^{-1}$ on day 91 day of operation. After day 91, the solids concentration decreased to around $1.5 \mathrm{~g} \mathrm{VSS} \mathrm{L}^{-1}$ (day 120) and remained at this value until the end of the experiment. The average VSS/TSS ratios of the reactor and effluent were 0.86 and $0.80 \mathrm{~g} \mathrm{SS} \mathrm{L}^{-1}$, respectively, and the suspended solids concentration of the effluent remained nearly constant around $0.1 \mathrm{~g}$ VSS $\mathrm{L}^{-1}$. The solids retention time (SRT) ranged from 8 to 26 days. Beun et al. (1999) reached SRT values around 50 days in a granular system. The lowest $\mathrm{SVI}_{10}$ and $\mathrm{SVI}_{30}$ values of 80 and $77 \mathrm{~mL} \mathrm{~g}$ $\mathrm{VSS}^{-1}$, respectively, were achieved when suspended solids reached their maximum concentration. 


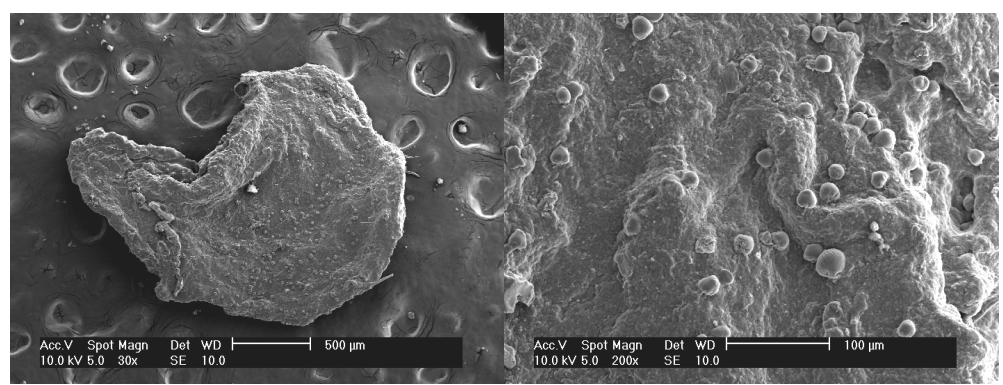

(a)

(b)

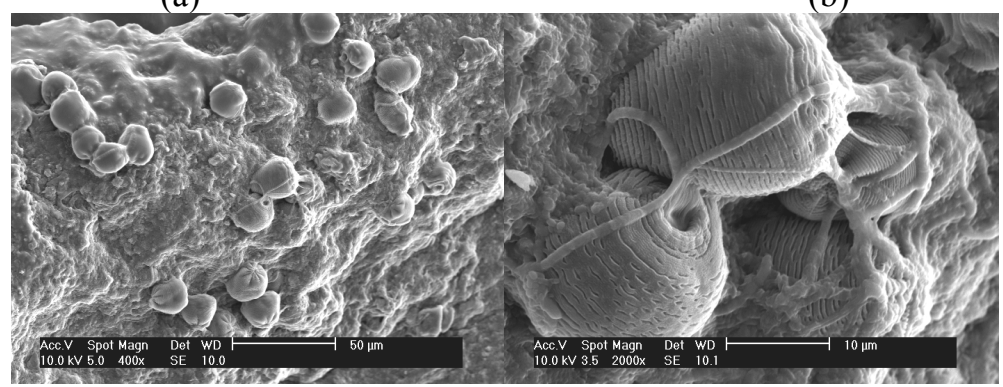

(c)

(d)

Figure 3: Granular sludge sample taken at day 84. (a) $500 \mu \mathrm{m}$; (b) $100 \mu \mathrm{m}$; (c) $50 \mu \mathrm{m}$; and (d) $10 \mu \mathrm{m}$.

For FISH, the EUB338 mix showed positive results for organisms belonging to the domain Bacteria. Additionally, an important portion of these bacteria belonged to $\beta$-Proteobacteria, and AOBs were also detected by using the Nso 190 probe. Most of the AOBs were identified as Nitrosomonas spp. by the NEU653 probe. The NIT3 probe also yielded positive results, indicating the presence of Nitrobacter spp. and/or Nitrospira spp..

\section{Organic Matter Removal}

Because the inlet Soluble Chemical Oxygen Demand (sCOD) concentration fluctuated between 422 and $817 \mathrm{mg} \mathrm{sCODL}^{-1}$, the applied Organic Loading Rate (OLR) ranged from 1.77 to $3.60 \mathrm{~g}$

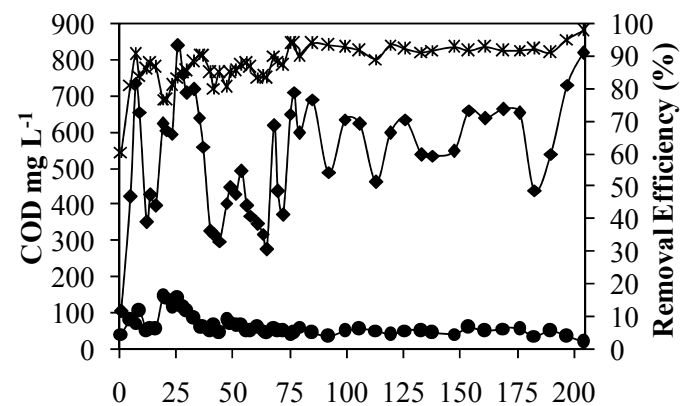

Operation Time (Days)

(a)
sCOD L $\mathrm{L}^{-1} \mathrm{~d}^{-1}$. In spite of this fact, the organic matter removal efficiency remained very stable at values around $75 \%$ from day 0 to 60 , which then reached $90 \%$ throughout the remainder of the operational period (Figure 4(a)). Wang et al. (2004) achieved a similar COD removal efficiency in an aerobic granular SBR treating synthetic wastewater at an OLR of $4.8 \mathrm{~g} \mathrm{COD} \mathrm{L}^{-1} \mathrm{~d}^{-1}$ under similar hydrodynamic conditions.

COD concentration was periodically tracked in the liquid phase during selected operational cycles in order to establish a COD profile. The COD measurements showed that organic matter was consumed during the first 20 minutes of aeration (feast period) at which time the DO concentration was around 4-6 $\mathrm{mg} \mathrm{O}_{2} \mathrm{~L}^{-1}$ (Figure 4(b)).

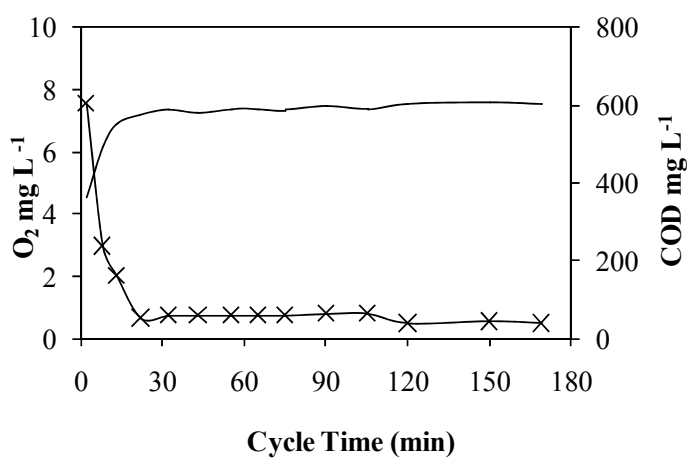

(b)

Figure 4: (a) Influent COD concentration ( $\bullet$ ); Effluent COD concentration ( $\bullet$ ); and removal COD efficiency $\left({ }^{*}\right)$ during operation. (b) COD concentration during an operational cycle on day 19. 


\section{Nitrogen and Phosphate Removal}

The ammonia loading rate (ALR) ranged from 0.1 to $0.36 \mathrm{~g} \mathrm{~N} \mathrm{~L}^{-1} \mathrm{~d}^{-1}$. Nitrification was already observed during the start-up period, although its efficiency fluctuated between 50 and $90 \%$ during the first 60 days of operation due to the fluctuations in the $\mathrm{pH}$ of the system (Figure 5(a)). After day 60, the $\mathrm{pH}$ value of the influent was adjusted in order to maintain stable nitrification.

Nitrite presence was always observed in the effluent and at a higher concentration than that of nitrate (Figure 5(a)). Nitrite accumulation is frequently described in these kinds of systems (Figueroa et al., 2008). This could be related to the effect limiting oxygen conditions have on the growth of NOBs during the operational cycles (Vázquez-Padín et al., 2010).

Average nitrogen removal was only $21 \%$, which indicated that denitrification was limited (Figure 5(b)). The mean COD/N ratio was 13.23 , and this value contributed to the denitrification that occurred.

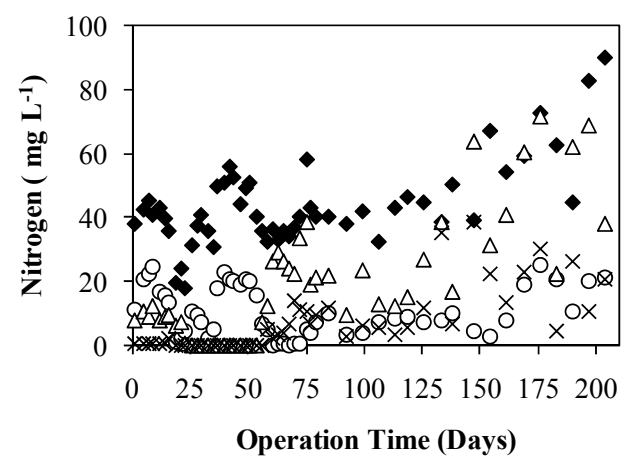

(a)

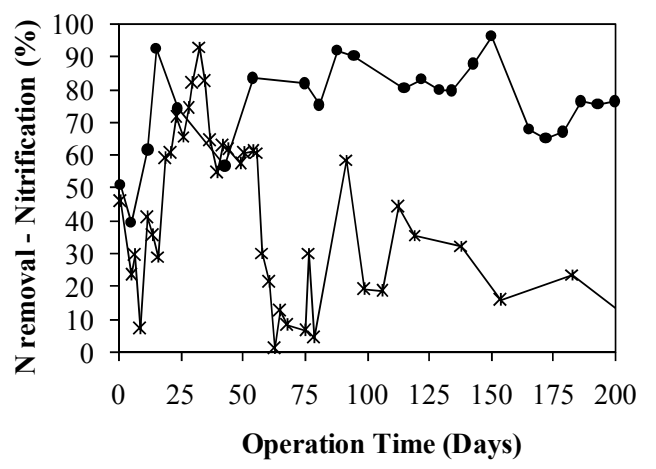

(b)

Figure 5: (a) Influent $\mathrm{NH}_{4}^{+}-\mathrm{N}(\diamond)$, effluent $\mathrm{NH}_{4}{ }^{+}-\mathrm{N}$ $(0)$, effluent $\mathrm{NO}_{2}-\mathrm{N}(\Delta)$, and effluent $\mathrm{NO}_{3}^{-}-\mathrm{N}(\times)$ in $\mathrm{mg} \mathrm{L}^{-1}$. (b) Nitrogen removal $(*)$ and nitrification $(\bullet)$ which is shown as a percent.

Nitrification is detected when the SRT is higher than 12 days (Sousa et al. 2008), and this agrees with the SRT values obtained during the operational period in this study. Zhou et al. (2007) also found that the aerobic granular SBR system can achieve high ammonia removal rates. In this study, a SRT of 2 to 3 days already reached ammonia removal percentages of around $80 \%$. This could be attributed to the relatively high influent temperatures $\left(16-27^{\circ} \mathrm{C}\right)$.

There was not a clear trend for phosphate removal efficiency. This was probably due to the changes in inlet phosphate concentrations (Figure 6). A maximum value of around $80 \%$ was achieved between 71 and 119 days.

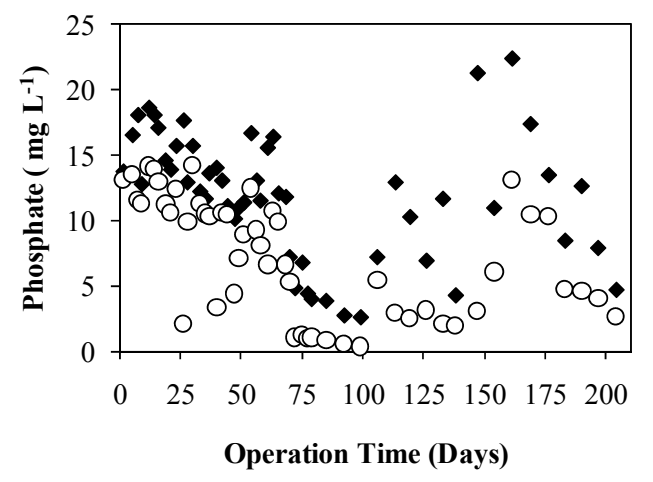

Figure 6: Influent $(\diamond)$ and effluent $(\circ)$ phosphate concentrations in $\mathrm{mg} \mathrm{L}^{-1}$.

\section{CONCLUSIONS}

Granule formation under the tested operational conditions occurred relatively quickly, only taking 30 days, and biomass concentrations up to $4 \mathrm{~g}$ VSS $\mathrm{L}^{-1}$ were achieved.

The system performance was stable in terms of organic matter and ammonia removal. Nitrification occurred throughout the entire operational period with an end product of primarily nitrite. However, the phosphorus removal efficiency fluctuated, which was probably due to the variations of inlet phosphate concentrations.

The system was able to achieve OLRs and ALRs up to $3.60 \mathrm{~g} \mathrm{COD} \mathrm{L}^{-1} \mathrm{~d}^{-1}$ and $0.36 \mathrm{~g} \mathrm{~N} \mathrm{~L}^{-1} \mathrm{~d}^{-1}$, respectively, under fluctuating conditions. This demonstrates the high capacity and flexibility of the system. Therefore, incorporating this system into small wastewater treatment plants may be a feasible option.

\section{ACKNOWLEDGMENTS}

This work was funded by the Brazilian National Research and Development Council (CNPq): Process 
number-556157/2006-0. The first author was supported by a scholarship (CNPq-CT-HIDRO and SWE). The authors were also funded by the Liquids and Gaseous Effluent Laboratory (LABEFLU) at the Department of Environmental Engineering at the Federal University of Santa Catarina (UFSC) in Brazil.

\section{REFERENCES}

Amann, R., Ludwig, W. and Schleifer, K. H., Phylogenetic identification and in-situ detectionof individual microbial-cells without cultivation. Microbiological Reviews, 59(1), 143-169 (1995).

APHA, Standard Methods for the Examination of Water and Wastewater, 21th Ed. American Public Health Association/American Water WorksAssociation/Water Environment Federation, Washington, DC (2005).

Arrojo, B., Mosquera-Corral, A., Garrido, J. M. and Mendez, R., Aerobic granulation with industrial wastewater in sequencing batch reactors. Water Research, 38, 3389-3399 (2004).

Beun, J. J., Hendriks, A., van Loosdrecht, M. C. M., Morgenroth, E., Wilderer, P. A. and Heijnen, J. J., Aerobic granulation in a sequencing batch reactor. Water Research, 33(10), 2283-2290 (1999).

de Bruin, L. M. M., van der Roest, H. F., de Kreuk, M. K. and van Loosdrecht, M. C. M., Promising results pilot research aerobic granular sludge technology at WWTP Ede. In: Aerobic Granular Sludge. Water and Environmental Management Series. IWA Publishing. Munich, pp.135-142 (2005).

de Kreuk, M. K., de Bruin, L. M. M. and van Loosdrecht, M. C. M., Aerobic granular sludge: From idea to pilot plant. In: Bathe, S., de Kreuk, M. K., Mc Swain, B. S., Schwarzenbeck, N., (Eds.), Aerobic Granular Sludge, IWA, London, pp. 111-123 (2005a).

de Kreuk, M. K., Pronk, M. and van Loosdrecht, M. C. M., Formation of aerobic granules and conversion processes in an aerobic granular sludge reactor at moderate and low temperatures. Water Research, 39, 4476-4484 (2005b).

de Kreuk, M. K. and van Loosdrecht, M. C. M., Formation of aerobic granules with domestic sewage. Journal of Environmental EngineeringASCE, 132, 694-697 (2006).

Figueroa, M., Mosquera-Corral, A., Campos, J. L. and Méndez, R., Treatment of saline wastewater in SBR aerobic granular reactors. Water Science and Technology, 58(2), 479-485 (2008).
Figueroa, M., Val Del Río, A., Morales, N., Campos, J. L., Mosquera-Corral, A., Mendez, R., Nitrogen Removal in Aerobic Granular Systems. In: Environmental Technologies to Treat Nitrogen Pollution, Principles and Engineering. Cervantes, F. J., (Ed.), IWA Publishing, London. 373-401 (2009).

Inizan, M., Freval, A., Cigana, J. and Meinhold, J., Aerobic granulation in a sequencing batch reactor (SBR) for industrial wastewater treatment. Water Science and Technology, 52, 335-343 (2005).

Jungles, M. K., Figueroa, M., Morales, N., Val Del Río, A., Costa, R. H. R., Campos, J. L., MosqueraCorral, A., Méndez, P., Start up of a pilot scale aerobic granular reactor for organic matter and nitrogen removal. J. Chem.TechnolBiotechnol., 86, 763-768 (2011).

Loy, A., Maixner, F., Wagner, M. and Horn, M., ProbeBase - an online resource for rRNA-targeted oligonucleotide probes: New features 2007. Nucleic Acids Research, 35, 800-804 (2007).

Ni, B. J., Xie, W. M., Liu, S. G., Yu, H. Q., Wang, Y. Z., Wang, G. and Dai, X. L., Granulation of activated sludge in a lab-scale sequencing batch reactor for the treatment of low-strength municipal wastewater. Water Research, 43(3), 751-761 (2009).

Ramalho, R. S., Introduction to Wastewater Treatment Processes. 2nd, Edition Academic Press. London (1991).

Schwarzenbeck, N., Borges, J. M. and Wilderer, P. A., Treatment of dairy effluents in an aerobic granular sludge sequencing batch reactor. Applied Microbiology and Biotechnology, 66, 711-718 (2005).

Soto, M., Veiga, M. C. Mendez, R. and Lema, J. M., Semi-micro C.O.D. determination method for high-salinity wastewater. Environmental Technology Letters, 10, 541-548 (1989).

Sousa, J. T., Henrrique, I. N., Oliveira, R., Lopes, W. S. Leite, V. D., Nitrification in a submerged attached growth bioreactor using Luffa cylindrica as solid substrate. African Journal of Biotechnology. 7(15), 2702-2706 (2008).

Tay, J. H., Tay, S. T., Ivanov, V., Pan, S., Jiang, H. L., Liu, Q. S., Biomass and porosity profiles in microbial granules used for aerobic wastewater treatment. Letters in Applied Microbiology, 36(5), 297-301 (2003).

Tay, J. H., Liu, Q. S., Liu, Y., Show, K. Y., Ivanov, V. and Tay, S. T. L., A Comparative Study of Aerobic Granulation in Pilot- and Laboratory Scale SBRs. In: Aerobic Granular Sludge. Water and Environmental Management Series. IWA Publishing. Munich, 125-133 (2005). 
Tijhuis, L., van Benthum, W. A. J., van Loosdrecht, M. C. M. and Heijnen, J. J., Solids retention time in spherical biofilms in a biofilm airlift suspension reactor. Biotechnology and Bioengineering, 44, 867-879 (1994).

Vázquez-Padín, J. R., Figueroa, M., Campos, J. L., Mosquera-Corral, A., Méndez, R., Nitrifying granular systems: A suitable technology to obtain stable partial nitrification at room temperature. Separation and Purification Technology, 74, 178186 (2010).

Wang, Q., Dua, G., Chena, J., Aerobic granular sludge cultivated under the selective pressure as a driving force. Process Biochemistry, 39, 557-563 (2004).

Wang, S. G., Liu, X. W., Gong, W. X., Gao, B. Y., Zhang, D. H. and Yu, H. Q., Aerobic granulation with brewery wastewater in a sequencing batch reactor. Bioresource Technology, 98(11), 21422147 (2007).

Weber, S. D., Ludwig, W., Schleifer, K.-H. and Fried, J., Microbial composition and structure of aerobic granular sewage biofilms. Applied and Environmental Microbiology, 73(19), 6233-6240 (2007).

Zhang, L., Zhang, B., Huang, Y. F \& Cai, W. M., Application of aerobic granular sludge in polishing the UASB effluent. Environmental Technology, 26(12), 1327-1334 (2005).

Zhou, J., Yang Feng-Lin, Meng Fan-gang, An, P., Wang, D., Comparison of membrane fouling during short-term filtration of aerobic granular sludge and activated sludge. Journal of Environmental Sciences, 19, 1281-1286 (2007). 